\title{
Supervisi Edukatif Kolaboratif untuk Meningkatkan Kinerja Guru Merencanakan Kegiatan Pembelajaran di SDN 01/X Rantau Indah Semester Ganjil Tahun Ajaran 2021/2022
}

\author{
Rosidah \\ SDN 01/X Rantau Indah \\ Jl. Rantau Indah, Dendang, Kabupaten Tanjung Jabung Timur, Jambi \\ rosidah@gmail.com
}

\begin{abstract}
This study aims to obtain information and discuss collaborative educational supervision to improve teacher performance in planning learning activities at SDN 01/X Rantau Indah in the odd semester of the 2021/2022 academic year. This type of research is school action research which consists of two cycles with each cycle consisting of four stages, namely planning, implementation, observation, and reflection. This research was conducted at SDN 01/X Rantau Indah in the odd semester of the 2021/2022 academic year with the subject of teacher research at SDN 01/X Rantau Indah totaling 7 people consisting of 6 class teachers and 1 PAI teacher. Data collection techniques using observation, field notes, interviews, and documentation. Data were analyzed using percentages and data reduction. The results showed that through collaborative educative supervision could improve teacher performance in classroom learning at SDN 01/X Rantau Indah.
\end{abstract}

Keywords: teacher performance, educational supervision, learning activities

\begin{abstract}
Abstrak
Penelitian ini bertujuan untuk mendapatkan informasi dan membahas tentang supervisi edukatif kolaboratif untuk meningkatkan kinerja guru merencanakan kegiatan pembelajaran di SDN 01/X Rantau Indah semester ganjil tahun ajaran 2021/2022. Jenis penelitian ini adalah penelitian tindakan sekolah yang terdiri dari dua siklus dengan masing-masing siklus terdiri dari empat tahapan yaitu perencanaan, pelaksanaan, observasi dan refleksi. Penelitian ini dilaksanakan di SDN 01/X Rantau Indah pada semester ganjil tahun ajaran 2021/2022 dengan subjek penelitian guru di SDN 01/X Rantau Indah yang berjumlah sebanyak 7 orang yang terdiri dari 6 orang guru kelas dan 1 orang guru PAI. Teknik pengumpulan data menggunakan observasi, catatan lapangan, wawancara dan dokumentasi. Data dianalisis menggunakan persentase dan reduksi data. Hasil penelitian menunjukkan bahwa melalui melalui supervisi edukatif kolaboratif dapat meningkatkan kinerja guru dalam pembelajaran di kelas di SDN 01/X Rantau Indah.
\end{abstract}

Kata kunci: kinerja guru, supervisi edukatif, kegiatan pembelajaran

Copyright (c) 2022 Rosidah

Corresponding author: Rosidah

Email Address: rosidah@gmail.com (Jl. Rantau Indah, Dendang, Kabupaten Tanjung Jabung Timur, Jambi)

Received 10 January 2022, Accepted 20 January 2022, Published 31 January 2022

\section{PENDAHULUAN}

Seorang guru harus selalu meningkatkan kemampuan profesionalnya, pengetahuan, sikap dan keterampilannya secara terus menerus sesuai perkembangan ilmu pengetahuan dan teknologi. Guru adalah pendidik profesional dengan tugas utama: mendidik, mengajar, membimbing, mengarahkan, melatih, menilai, dan mengevaluasi peserta didik pada pendidikan anak usia dini jalur pendidikan formal, pendidikan dasar dan pendidikan menengah (UU Guru pasal 1 ayat 1, 2006). Dalam rangka meningkatkan mutu pendidikan di Indonesia, pemerintah telah menetapkan Undang-Undang. Sistem Pendidikan. Undang-undang tersebut menjelaskan bahwa setiap perubahan sistem pendidikan nasional untuk memperbarui visi, misi dan strategi pembangunan pendidikan nasional (UU Sisdiknas, 2003:37). Adapun visi pendidikan nasional di antaranya adalah (1) mengupayakan perluasan dan 
pemerataan kesempatan memperoleh pendidikan yang bermutu bagi seluruh rakyat Indonesia, (2) membantu dan memfasilitasi pengembangan potensi anak bangsa secara utuh sejak usia dini sampai akhir hayat dalam rangka mewujudkan masyarakat belajar, (3) meningkatkan kesiapan masukan dan kualitas proses pendidikan untuk mengoptimalkan pembentukan kepribadian yang bermoral, (4) meningkatkan keprofesionalan dan akuntabilitas lembaga pendidikan sebagai pusat pembudayaan ilmu pengetahuan, keterampilan, pengalaman, sikap, dan nilai berdasarkan standar nasional dan global (Rulyansah \& Sholihati, 2018), (5) Memperdayakan peran serta masyarakat dalam penyelenggaraan pendidikan berdasarkan prinsip otonomi dalam konteks Negara Kesatuan RI.

Beradasarkan hasil observasi yang dilakukan oleh peneliti (kepala sekolah) di SDN 01/X Rantau Indah, didapat hasil bahwa kinerja guru dalam merencanakan kegiatan pembelajaran masih rendah. rendahnya kinerja dan wawasan guru diakibatkan (1) rendahnya kesadaran guru untuk belajar, (2) kurangnya kesempatan guru mengikuti pelatihan, baik secara regional maupun nasional, (3) kurang efektifnya PKG, (4) supervisi pendidikan yang bertujuan memperbaiki proses pembelajaran cenderung menitikberatkan pada aspek administrasi.

Untuk menangani masalah tersebut, salah satu solusi yang dapat dilakukan adalah dengan menggunakan metode Supervisi Edukatif Kolaboratif yang difokuskan pada supervisi Edukatif saja. Dengan demikian, diharapkan keterampilan guru bertambah dan dapat meningkatkan kinerja dan wawasan guru dengan memuaskan.

Supervisi merupakan salah satu tugas kepala sekolah yang bertujuan untuk memperbaiki dan meningkatkan pengelolaan dari aspek yang di supervise dan orang yang melakukan supervisi. Supervisi edukatif merupakan supervisi yang diarahkan pada kurikulum, pembelajaran proses belajar mengajar, pelaksanaan bimbingan dan konseling. Menurut Ditjen Dikmenum (1994:15) pelaksanaan supervis tersebut dapat dilakukan dengan cara: (1). Wawancara, (2). Observasi. Jika supervisi dilakukan pengawas kepada kepala sekolah, pengawas bisa melaksanakan wawancara dengan kepala sekolah yang berkaitan dengan kelengkapan dokumen kurikulum. Selain wawancara, pengawas dan atau kepala sekolah dapat melaksanakan observasi kepada guru dalam proses belajar mengajar atau dalam kegiatan bimbingan konseling. Untuk memperbaiki kinerja dan wawasan guru dalam pembelajaran di SDN 01/X Rantau Indah, sekolah melaksanakan penelitian tindakan yang berkaitan dengan permasalahan di atas. Karena keterbatasan peneliti, maka penelitian ini hanya divokuskan pada supervisi edukatif saja sehingga peneliti mengadakan penelitian yang bertujuan untuk mendapatkan informasi dan membahas tentang supervisi edukatif kolaboratif untuk meningkatkan kinerja guru merencanakan kegiatan pembelajaran di SDN 01/X Rantau Indah semester ganjil tahun ajaran 2021/2022.

Guru memiliki peran penting dalam mencapai tujuan pendidikan. Pendapat Slameto (2012) bahwa kualitas pendidikan, terutama ditentukan oleh proses belajar mengajar yang berlangsung diruang kelas. Dalam proses belajar mengajar tersebut guru memegang peran yang penting. Guru adalah motivator atau pendorong dalam proses kegiatan belajar mengajar. Menurut Broke and Stone 
Supervisi Edukatif Kolaboratif untuk Meningkatkan Kinerja Guru Merencanakan Kegiatan Pembelajaran di SDN 01/X Rantau Indah Semester Ganjil Tahun Ajaran 2021/2022, Rosidah

sebagaimana dikutip Mulyasa (2007:25), kompetensi guru merupakan gambaran kualitatif tentang hakikat guru yang penuh arti. Sedangkan dalam Undang-Undang Nomor 14 Tahun 2005 dijelaskan bahwa: "Kompetensi adalah seperangkat pengetahuan, keterampilan, yang harus dimiliki, dihayati, dan dikuasai oleh guru dalam melaksanakan tugas keprofosionalnya".

Peran guru yang dimaksud adalah berkaitan dengan peran guru dalam proses pembelajaran. Menurut Rivai (2004), kinerja guru adalah: perilaku nyata yang ditampilkan oleh guru sebagai prestasi kerja berdasarkan standar yang ditetapkan dan sesuai dengan perannya di sekolah. Guru merupakan perencana, pelaksana sekaligus sebagai evaluator pembelajaran di kelas (Gunawan dalam Ondi Saondi, 2010). Guru merupakan faktor penentu yang sangat dominan dalam pendidikan pada umumnya, karena guru memegang peranan dalam proses pembelajaran, dimana proses pembelajaran merupakan inti dari proses pendidikan secara keseluruhan.

Kinerja adalah serangkaian kegiatan yang menggambarkan sejauhmana hasil yang sudah dicapai oleh seseorang dalam melaksanakan tugas dan tanggung jawabnya dalam bentuk akuntabilitas publik, baik berupa keberhasilan maupun kekurangan yang terjadi. Sedangkan menurut Rivai dan Mohd Basri (2005) bahwa kinerja adalah hasil atau tindakan keberhasilan seseorang secara keseluruhan selama beberapa periode tertentu dalam melaksanakan tugas dibandingkan dengan berbagai kemungkinan, seperti standar hasil kerja, target atau sasaran kriteria yang telah ditentukan terlebih dahulu telah disepakati bersama.

Selain itu, Sulistiyani (2003), kinerja seseorang merupakan kombinasi dari kemampuan, usaha, dan kesempatan yang dapat dinilai dari hasil kerjanya. Sedangkan menurut Bernardin dan Russel dalam Sulistiyani (2003) menyatakan bahwa kinerja merupakan catatan outcome yang dihasilkan dari fungsi pegawai tertentu atau kegiatan yang dilakukan selama periode waktu tertentu.

Kinerja guru mempunyai spesifikasi tertentu. Kinerja guru dapat dilihat dan diukur berdasarkan spesifikasi atau kriteria kompetensi yang harus dimiliki oleh setiap guru. Berkaitan dengan kinerja guru, wujud perilaku yang dimaksud adalah kegiatan guru dalam proses pembelajaran. Standar kinerja guru itu berhubungan dengan kualitas guru dalam menjalankan tugasnya seperti: (1) bekerja dengan siswa secara individual, (2) persiapan dan perencanaan pembelajaran, (3) pendayagunaan media pembelajaran, (4) melibatkan siswa dalam berbagai pengalaman belajar, dan (5) kepemimpinan yang aktif dari guru".

UU Republik Indonesia No. 20 Tahun 2003 tentang Sisdiknas pasal 39 ayat (2), menyatakan bahwa pendidik merupakan tenaga profesional yang bertugas merencanakan dan melaksanakan proses pembelajaran, menilai hasil pembelajaran, melakukan pembimbingan dan pelatihan serta melakukan penelitian dan pengabdian kepada masyarakat, terutama bagi pendidik pada perguruan tinggi.

Menurut Mathis dan Jackson (2006) kinerja guru adalah yang mempengaruhi seberapa banyak mereka memberi kontribusi kepada organisasi." Berdasarkan pendapatdi atas maka perbaikan kinerja baik untuk individu maupun kelompok menjadi pasal perhatian dalam upaya meningkatkan kinerja organisasi sekolah. Kuswana (2008) mengemukakan bahwa kinerja guru 
dikatakan berhasil apabila, memberikan efek terhadap perkembangan potensi siswa dalam konteks psikologis dan fisik, yakni bersifat positif terhadap apa yang dipelajarinya, baik dilihat dari tujuan serta manfaatnya. Sehingga kecerdasan kognitif, efektif dan psikomotif berkembang. Intinya apakah terjadi perubahan perilaku, berfikir sistematis dan terampil mengenai apa yang terjadi.

Dari beberapa pengertian kinerja di atas, peneliti dapat menarik kesimpulan bahwa kinerja guru merupakan suatu kemampuan kerja atau prestasi kerja yang diperlihatkan oleh seorang guru untuk memperoleh hasil kerja yang optimaldalam kurun waktu tertentu. Penilaian Kinerja seorang guru akan nampak pada situasi dan kondisi belajar mengajar selama satut ahun ajaran. Aktivitas-aktivitas yang dilakukan oleh seseorang guru dalam melaksanakan pekerjaannya menggambarkan bagaimana ia berusaha mencapai tujuan yang telah ditetapkan.

Supervisi merupakan salah satu tugas kepala sekolah yang bertujuan untuk membantu memperbaiki dan meningkatkan pengelolaan dari aspek yang disupervisi dan orang yang melakukan supervisi. Aspek yang disupervisi bisa berupa administrasi, dan edukatif, sedangkan orang yang melakukan supervisi adalah pengawas, kepala sekolah, instruktur mata pelajaran. Adapun orang yang disupervisi bisa kepala sekolah, guru mata pelajaran, guru pembimbing, tenaga edukatif yang lain, tenaga administrasi, dan siswa.

Supervisi ialah suatu aktifitas pembinaan yang direncanakan untuk membantu para guru dan pegawai sekolah lainnya dalam melakukan pekerjaan secara efektif (Purwanto,2000). Manullang (2005) menyatakan bahwa supervisi merupakan proses untuk menerapkan pekerjaan apa yang sudah dilaksanakan, menilainya dan bila perlu mengkoreksi dengan maksud supaya pelaksanaan pekerjaan sesuai dengan rencana semula. Supervisi merupakan usaha memberi pelayanan agar guru menjadi lebih profesional dalam menjalankan tugas melayani peserta didik.

Supervisi edukatif merupakan supervisi yang diarahkan pada kurikulum pembelajaran, proses belajar mengajar, pelaksanaan bimbingan dan konseling. Supervisi ini dapat dilakukan oleh pengawas, kepala sekolah, maupun guru senior yang sudah pernah menjadi instruktur mata pelajaran. Menurut Dirjen Dikmenum (1884) pelaksanaan supervisi tersebut dapat dilakukan dengan cara (1) wawancara, (2) observasi.

Jadi pada hakikatnya, supervisi adalah sebagai bantuan dan bimbingan atau tuntunan profesional bagi guru dalam melaksanakan tugas instruksional guna memperbaiki hal belajar dan mengajar dengan melakukan stimulasi, koordinasi, dan bimbingan secara kontinu sebagai bagian dari peningkatan mutu pembelajaran.

\section{METODE}

Jenis penelitian ini adalah penelitian tindakan sekolah yang terdiri dari dua siklus dengan masing-masing siklus terdiri dari empat tahapan yaitu perencanaan, pelaksanaan, observasi dan refleksi. Penelitian ini dilaksanakan di SDN 01/X Rantau Indah pada semester ganjil tahun ajaran 2021/2022 dengan subjek penelitian guru di SDN 01/X Rantau Indah yang berjumlah sebanyak 7 
Supervisi Edukatif Kolaboratif untuk Meningkatkan Kinerja Guru Merencanakan Kegiatan Pembelajaran di SDN 01/X Rantau Indah Semester Ganjil Tahun Ajaran 2021/2022, Rosidah

orang yang terdiri dari 6 orang guru kelas dan 1 orang guru PAI. Teknik pengumpulan data menggunakan observasi, catatan lapangan, wawancara dan dokumentasi. Data dianalisis menggunakan persentase dan reduksi data.

\section{HASIL DAN DISKUSI}

Siklus I

Berdasarkan pemantauan selama persiapan, pelaksanaan, dan tindak lanjut penelitian tindakan ini diperoleh berbagai data baik dari guru yang sedang melaksanakan proses belajar mengajar, siswa yang belajar, Peneliti yang sedang melaksanakan supervisisnya. Gambaran yang merupakan hasil dan temuan penelitian sebagai berikut.

\section{Perencanaan}

Peneliti bersama guru membuat perencanaan yang berkaitan dengan pembuatan instrumen penelitian. Instrumen tersebut dibuat berdasarkan pada indikator yang dibuat oleh Departemen Pendidikan Nasional. Hasil pemantauan sebagai berikut.

Pembuatan format penilaian pra-KBM sebagai berikut; 1) Mendeskripsikan tujuan pembelajaran, 2) Menentukan materi sesuai dengan kompetensi yang telah ditentukan, 3) Mengorganisasikan materi berdasarkan urutan dan kelompok, 4) Mengalokasikan waktu, 5) Menentukan metode pembelajaran yang sesuai, 6) Merancang prosedur pembelajaran, 7) Menentukan media pembelajaran/peralatan praktikum (dan bahan) yang akan digunakanMenentukan sumber belajar yang sesuai (berupa buku, modul, program komputer dan sejenisnya), 8) Menentukan teknik .

\section{Pelaksanaan}

Tahap pelaksanaan siklus I dilaksanakan selama 3 kali pertemuan yaitu pada hari Selasa tanggal 12 Oktober 2021, hari Kamis tanggal 14 Oktober 2021, dan hari Senin tanggal 18 Oktober 2021. Proses supervisi dimulai dengan memberi pengantar tentang maksud pertemuan dan kemudian diikuti oleh uraian singkat tentang hal yang akan dibahas atau kasus tertentu yang akan menjadi bahan pembicaraan. Selesai memberikan pengantar, uraian singkat, atau menginformasikan kasus ini, tanya jawab dimulai. Diskusi yang hangat dan perdebatan mungkin terjadi. Hal itu sangat baik dilakukan asalkan mengarah kepada pemantapan pemahaman tentang hal-hal yang dibahas yang sebelumnya dipandang belum banyak dipahami oleh guru-guru.

Tindakan Peneliti pada pelaksanaan supervisi siklus pertama sebagai berikut. (1) Peneliti memeberikan indikator yang harus dicapai pada saat persiapan, pelaksanaan, dan penilaian seminggu sebelum pelaksanaan supervisi, (2) Peneliti menyuruh guru mengisi format penilaian serta membuat perencanaan kembali kegiatan berikut yang akan disupervisi.

Pada tahap ini peneliti supervisi tidak hanya membicarakan materi pelajaran dan proses pembelajaran saja seperti kebanyakan pada supervisi individual, tetapi juga membahas tentang upayaupaya meningkatkan profesi guru. Upaya yang dimaksud antara lain adalah cara-cara agar guru berdedikasi pada tugasnya, meningkatkan kepribadian, benar-benar belajar seumur hidup, bisa bekerja 
sama secara baik dengan orang tua siswa, bisa menganalisa kondisi daerah dalam rangka melaksanakan kurikulum lokal, bisa menjadi agen pembaruan masyarakat, dan sebagainya.

\section{Observasi}

Hasil siklus pertama dapat dilihat pada tabel berikut ini:

Tabel 1. Hasil Melaksanakan Pembelajaran Tindakan Siklus I

\begin{tabular}{|c|l|c|c|c|c|}
\hline No & \multicolumn{1}{|c|}{ Indikator } & Jumlah & $\begin{array}{c}\text { Rata- } \\
\text { Rata }\end{array}$ & \% & Kategori \\
\hline 1 & $\begin{array}{l}\text { Membuka pelajaran dengan metode } \\
\text { yang tepat }\end{array}$ & 19 & 2.71 & 68 & $\mathrm{C}$ \\
\hline 2 & $\begin{array}{l}\text { Menyajikan materi pelajaran secara } \\
\text { sistematis }\end{array}$ & 19 & 2.71 & 68 & $\mathrm{C}$ \\
\hline 3 & $\begin{array}{l}\text { Menerapkan metode dan prosedur } \\
\text { pembelajaran yang telah ditentukan }\end{array}$ & 21 & 3.00 & 75 & $\mathrm{~B}$ \\
\hline 4 & Mengatur kegiatan siswa di kelas & 18 & 2.57 & 64 & $\mathrm{C}$ \\
\hline 5 & Menentukan media pembelajaran & 21 & 3.00 & 75 & $\mathrm{~B}$ \\
\hline 6 & Menggunakan sumber belajar & 20 & 2.86 & 71 & $\mathrm{~B}$ \\
\hline 7 & $\begin{array}{l}\text { Memotivasi siswa dengan berbagai cara } \\
\text { yang positif }\end{array}$ & 22 & 3.14 & 79 & $\mathrm{~B}$ \\
\hline 8 & $\begin{array}{l}\text { Melakukan interaksi dengan siswa } \\
\text { menggunakan bahasa yang komunikatif }\end{array}$ & 19 & 2.71 & 68 & $\mathrm{C}$ \\
\hline 9 & $\begin{array}{l}\text { Memberikan pertanyaan dan umpan } \\
\text { balik }\end{array}$ & 22 & 3.14 & 79 & $\mathrm{~B}$ \\
\hline 10 & Menyimpulkan pembelajaran & 14 & 2.00 & 50 & $\mathrm{D}$ \\
\hline
\end{tabular}

Berdasarkan tabel di atas dapat dijelaskan bahwa pada siklus I ada 10 indikator penilaian yang dilakukan oleh peneliti (kepala sekolah) untuk melihat kinerja guru dalam merancang pembelajaran. Dari 10 indikator tersebut secara keseluruhan berada pada kategori cukup. Kemampuan guru dalam menerapkan metode dan prosedur pembelajaran yang telah ditentukan, menentukan media pembelajaran, menggunakan sumber belajara, memotivasi siswa dengan berbagai cara yang positif, dan memberikan pertanyaan serta umpan balik, semua indikator tersebut sudah berada pada kategori baik. Namun masih ada indikator yang berada pada kategori cukup yaitu Membuka pelajaran dengan metode yang tepat, Menyajikan materi pelajaran secara sistematis, serta Melakukan interaksi dengan siswa menggunakan bahasa yang komunikatif masih berada pada kategori cukup. Sedangkan indikator dalam menyimpulkan pembelajaran masih berada pada kategori kurang, untuk itu perlu adanya perbaikan pada siklus berikutnya. Untuk melihat persesntase ketuntasan guru dapat dilihat pada tabel berikut ini:

Tabel 2. Persentase Ketuntasan Guru Pada Siklus I

\begin{tabular}{|c|l|c|c|c|c|}
\hline No & \multicolumn{1}{|c|}{ Nama Guru } & Jumlah & Rata-Rata & $\%$ & Kategori \\
\hline 1 & Lismawat, S.Pd. & 30 & 3.00 & 75 & B \\
\hline 2 & Despi Wulandari, S.Pd & 31 & 3.10 & 78 & B \\
\hline 3 & Dedek Wijayanti, S.Pd & 25 & 2.50 & 63 & C \\
\hline 4 & Hermiyati, S.Pd.SD & 27 & 2.70 & 68 & C \\
\hline
\end{tabular}


Supervisi Edukatif Kolaboratif untuk Meningkatkan Kinerja Guru Merencanakan Kegiatan Pembelajaran di SDN 01/X Rantau Indah Semester Ganjil Tahun Ajaran 2021/2022, Rosidah

\begin{tabular}{|l|l|l|l|l|l|}
\hline 5 & Rosdiana Siregar, S.Pd.SD & 24 & 2.40 & 60 & C \\
\hline 6 & Setiarna.S, S.Pd.SD & 31 & 3.10 & 78 & B \\
\hline 7 & Sudirman, S.Pd.I & 27 & 2.70 & 68 & C \\
\hline
\end{tabular}

Berdasarkan tabel di atas dapat disimpulkan bahwa kemampuan guru dalam merancang kegiatan pembelajaran masih rendah. Dilihat dari indikator yang yang dinilai masih banyak gurun yang berada di bawah kriteria ketuntasan yang diharapkan. Dari 7 orang guru yang diteliti berada pada rata-rata cukup. Dari 10 indikator yang dinilai hanya 3 orang guru yang mampu dalam memenuhi indikator yang dinilai. Untuk itu perlu diadakan perbaikan-perbaikan untuk pertemuan selanjutnya.

\section{Refleksi}

Tahap refleksi dilaksanakan pada hari Jumat tanngal 22 Oktober 2021 yang dibantu oleh seorang obeserver yang bernama Tismia, S.Pd. kelas dan bertempat di rungan kepala SDN 01/X Rantau Indah. Berdasarkan deskripsi dan refleksi di atas, peneliti, guru dan Peneliti melakukan tindak lanjut yang berkaitan dengan tindakan-tindakan yang perlu dilakukan pada siklus kedua, baik yang berkaitan dengan perencanaan, pelaksanaan, maupun penilaian. Guru yang disupervisi dibantu oleh Peneliti membuat perencanaan pembelajaran yang kriterianya berdasarkan pada indikator yang telah dibuat oleh Dirjen Dikmenum dengan memperhatikan: (1) Memperjelas tujuan pembelajaran yang ada dalam GBPP/ Kurikulum yang berlaku dengan membuat tujuan khusus pembelajaran (2) Materi pembelajaran dibuat sesederhana mungkin dan urut dari yang sederhana ke yang sulit. Materi itu ditulis di RPP guru, (3) Menentukan pembagian alokasi waktu secara spisifik dan berdasarkan pada langkah-langkah pembelajaran dan metodenya, (4) Menentukan media pembelajaran secara kontekstual dan berdasarkan pada materi yang dipelajari siswa, (5) Teknik penilaian didasarkan pada keterampilan atau materi yang diberikan.

Pada siklus I pelaksanaan supervisi difokuskan pada kerja sama dalam pembelajaran di kelas. Guru senior atau guru yang sudah mampu membantu pada guru yunior atau guru yang belum mampu dalam pelaksanaan pembelajaran. Contoh-contoh pembelajaran perlu diperhatikan oleh guru yang belum mampu tersebut, terutama melakukan hal-hal berikut. 1) Guru senior atau yang sudah mampu melaksanakan pembelajaran memberi contoh pada guru yunior (guru yang belum mampu) dalam membuka pelajaran dengan cara apersepsi dan menggali skemata siswa yang berkaitan dengan materi sebelumnya, 2) Guru melaksanakan pembelajaran sesuai dengan perencanaan yang dibuat bersama dengan memperhatikan langkah-langkah yang ada dalam RPP, 3) Penggunaan media difokuskan pada benda-benda yang ada di lingkungan sekolah. Tentu saja disesuaikan dengan materi yang dipelajari siswa, 4) Guru membagi papan tulis menjadi tiga bagian, yakni bagian pertama digunakan untuk menulis tujuan yang ingin dicapai. Bagian kedua untuk tanya jawab atau tulisan yang berkaitan dengan proses pembelajaran. Bagian ketiga digunakan untuk kesimpulan.

Pada bagian penilaian ini guru berdiskusi dengan guru lain untuk menentukan penilaian yang cocok untuk pokok bahasan atau KD yang akan disampaikan pada siswa. Hal yang perlu dilaksanakan 
sebagai perbaikan siklus I adalah: (1) Pembuatan kisi-kisi ulangan dititikberatkan pada ulangan uraian objektif dan satu uraian non objektif, (2) Pelaksanaan penilaian dikelompokkan menjadi dua, yakni dalam proses, yang soalnya berupa pertanyaan yang dijawab secara langsung oleh siswa, kedua soalsoal yang dibuat untuk dikerjakan setelah proses pembelajaran, (3) Guru selalu mendiskusikan dengan teman guru atau dengan Peneliti untuk menentukan skor, bobot, analisis butir soal, dan perbaikan soal, menyimpulkan hasil dan melaporkan hasil penilaian.

\section{Siklus II}

\section{Perencanaan}

Tahap perencanaan siklus II terdiri dari: 1) Peneliti berkoordinasi dengan kepala sekolah untuk menyampaikan materi penelitian dan minta masukan tentang masalah yang ada sekaligus membicarakan masalah teknis, waktu pelaksanaan penelitian untuk siklus II, 2) Bersama kepala sekolah menyiapakna materi bimbingan untuk siklus II, 3) Peneliti mengidentifikasi permasalahan yang ditemukan, 4) Menyusun rencana tindakan (berupa penjadwalan bimbingan individual disesuaikan dengan temuan pada identifikasi masalah).

\section{Pelaksanaan}

Tahap pelaksnaan siklus 2 dimulai pada hari Senin tanggal tangal 1 November 2021, hari Rabu tanggal 3 November 2021, dan hari Senin tangaal 8 November 2021. Instrumen penelitian pada siklus II tetap menggunakan instrumen yang dibuat oleh pemerintah. Tindakan Peneliti pada pelaksanaan supervisi siklus kedua sebagai berikut. (1) Peneliti memeberikan indikator yang harus dicapai pada saat persiapan, pelaksanaan, dan penilaian seminggu sebelum pelaksanaan supervisi. Guru yang disupervisi diajak diskusi tentang format tersebut, (2) Peneliti menyuruh guru mengisi format penilaian yang ingin dicapai, satu minggu sebelum pelaksanaan supervisi, (3) Peneliti mendiskusikan persiapan dengan guru yang akan disupervisi, (4) Peneliti mengamati guru pada saat supervisi dengan cara berkolaborasi secara langsung dalam PBM, (5) Peneliti berdiskusi dengan guru setelah melaksanakan supervisi, (6) Guru dan Peneliti menganalis hasil belajar siswa dan membuat laporan bersama tentang pembelajaran. (7) Guru dan Peneliti menganalisis program yang telah dibuat untuk diperbaiki jika kurang sesuasi.

\section{Observasi}

Setelah tahap pelaksanaan supervisi kolaboratif edukatif yang dilakukan oleh peneliti dan dibantu oleh seorang observer maka didapat hasi pengamatan yang dapat dilihat pada tabel berikut ini:

Tabel 3. Hasil Melaksanakan Pembelajaran Tindakan Siklus II

\begin{tabular}{|c|c|c|c|c|c|}
\hline No & Indikator & Jumlah & $\begin{array}{l}\text { Rata- } \\
\text { Rata }\end{array}$ & $\%$ & Kategori \\
\hline 1 & $\begin{array}{l}\text { Membuka pelajaran dengan metode yang } \\
\text { tepat }\end{array}$ & 26 & 3.71 & 93 & A \\
\hline 2 & $\begin{array}{l}\text { Menyajikan materi pelajaran secara } \\
\text { sistematis }\end{array}$ & 22 & 3.14 & 79 & B \\
\hline
\end{tabular}


Supervisi Edukatif Kolaboratif untuk Meningkatkan Kinerja Guru Merencanakan Kegiatan Pembelajaran di SDN 01/X Rantau Indah Semester Ganjil Tahun Ajaran 2021/2022, Rosidah

\begin{tabular}{|c|l|c|c|c|c|}
\hline No & \multicolumn{1}{|c|}{ Indikator } & Jumlah & $\begin{array}{c}\text { Rata- } \\
\text { Rata }\end{array}$ & $\%$ & Kategori \\
\hline 3 & $\begin{array}{l}\text { Menerapkan metode dan prosedur } \\
\text { pembelajaran yang telah ditentukan }\end{array}$ & 25 & 3.57 & 89 & $\mathrm{~A}$ \\
\hline 4 & Mengatur kegiatan siswa di kelas & 22 & 3.14 & 79 & $\mathrm{~B}$ \\
\hline 5 & Menentukan media pembelajaran & 21 & 3.00 & 75 & $\mathrm{~B}$ \\
\hline 6 & Menggunakan sumber belajar & 24 & 3.43 & 86 & $\mathrm{~A}$ \\
\hline 7 & $\begin{array}{l}\text { Memotivasi siswa dengan berbagai cara } \\
\text { yang positif }\end{array}$ & 23 & 3.29 & 82 & $\mathrm{~A}$ \\
\hline 8 & $\begin{array}{l}\text { Melakukan interaksi dengan siswa } \\
\text { menggunakan bahasa yang komunikatif }\end{array}$ & 22 & 3.14 & 79 & $\mathrm{~A}$ \\
\hline 9 & Memberikan pertanyaan dan umpan balik & 26 & 3.71 & 93 & $\mathrm{~A}$ \\
\hline 10 & \begin{tabular}{l} 
Menyimpulkan pembelajaran \\
\hline
\end{tabular} & 21 & 3.00 & 75 & $\mathrm{~B}$ \\
\hline
\end{tabular}

Berdasarkan tabel di atas dapat disimpulkan bahwa kinerja guru pada siklus II sudah meningkat dibandingkan dari siklus I. Dilihat dari indikator penilaian kinerja guru didapat bahwa ratarata indikator penilaian sudah berada pada kategori baik dan sangat baik. Untuk melihat persentase ketuntasan masing-maisng guru dapat dilihat pada tabel berikut ini:

Tabel 4. Persentase Ketuntasan Guru pada Siklus II

\begin{tabular}{|c|l|c|c|c|c|}
\hline No & Nama Guru & Jumlah & $\begin{array}{l}\text { Rata- } \\
\text { Rata }\end{array}$ & $\%$ & Kategori \\
\hline 1 & Lismawati, S.Pd & 35 & 3.50 & 88 & A \\
\hline 2 & Despi Wulandari, S.Pd & 36 & 3.60 & 90 & A \\
\hline 3 & Dedek Wijayanti, S.Pd & 30 & 3.00 & 75 & B \\
\hline 4 & Hermiyati, S.Pd.SD & 30 & 3.00 & 75 & B \\
\hline 5 & Rosdiana Siregar, S.Pd.SD & 31 & 3.10 & 78 & B \\
\hline 6 & Setiarna.S, S.Pd.SD & 37 & 3.70 & 93 & A \\
\hline 7 & Sudirman, S.Pd.I & 33 & 3.30 & 83 & A \\
\hline
\end{tabular}

Berdasarkan tabel di atas dapat dilihat bahwa kemampuan guru dalam merancang kegiatan pembelajaran sudah meningkat dan berada pada kategori sangat baik. Hal ini dikarenakan dengan adanya supervisi edukatif dapat meningkatkan kemampuan guru. Kegiatan ini dilaksanakan oleh guru pada bagian terakhir setelah melaksanakan penilaian dengan tujuan menganalisis program penilaian dan perbaikan hasil penilaian.

\section{Refleksi}

Tahap refleksi siklus II dilaksanakn pada hari Rabu tanggal 10 November 2021 dengan dibantu oleh seorang observer yang bernama Tismia, S.Pd dan bertempat di ruangan kepala SDN 01/X Rantau Indah. Diskusi antara peneliti dan observer ini dilaksnakan di ruangan kepala sekolah. Setelah dilaksanakan diskusi dengan guru dan peneliti maka peneliti menulis hasil refleksi sebagai berikut. Berdasarkan deskripsi dan refleksi di atas, peneliti, guru dan Peneliti menghentikan penelitian tindakan ini karena hasil yang diperoleh setelah tindakan, baik yang dilakukan oleh peneliti maupun guru sudah memuaskan. 
Berdasarkan hasil penilaian terhadap kemampuan guru dalam merancang kegiatan pembelajaran dan pengamatan terhadap guru dalam kegiatan pembelajaran dapat direfleksi dan dievaluasi dapat disampaikan bahwa selama proses kegiatan supervisi edukatif para guru merasakan manfaat yang sangat banyak, terutama pengalaman yang selama ini jarang mereka lakukan dalam pengelolaan pembelajaran. Suasana pembelajaran juga terasa sangat mengasikkan, bukan saja bagi siswa melainkan para guru juga merasakan hal yang sama.

\section{Diskusi}

Pembahasan didasarkan pada teori-teori yang sudah ada, baik berdasarkan pada referensi mapun dari ucapan ahli di bidang penelitian ini. Adapun pembahasan hasil penelitian ini sebagai berikut. Temuan Pertama, kinerja guru meningkat dalam melaksanakan pembelajaran. Dalam penelitian tindakan ini ternyata dari 6 guru hampir semuanya mampu melaksanakan pembelajaran dengan baik. Hal ini terbukti dari hasil supervisi. Langkah-langkah yang dilakukan untuk meningkatkan pelaksanaan pembelajaran berdasarkan penelitian tindakan ini adalah: (1) Peneliti yang mengamati guru mengajar tidak sebagai penilai tetapi sebagai rekan bekerja yang siap membantu guru tersebut, (2) Selama pelaksaaan supervisi di di kelas guru tidak menganggap Peneliti sebagai penilai karena sebelum pelaksanaan supervisi guru dan Peneliti telah berdiskusi permasalahan-permasalahan yang ada dalam pembelajaran tersebut, (3) Peneliti mencatat semua peristiwa yang terjadi di dalam pembelajaran baik yang positif maupun yang negatif, (4) Peneliti selalu memberi contoh pembelajaran yang berorientasi pada Modern Learning. (5) Jika ada guru yang pembelajarannya kurang jelas tujuan, penyajian, umpan balik, Peneliti memberikan contoh bagaimana menjelaskan tujuan, menyajikan, memberi umpan balik kepada guru tersebut, (6) Setelah guru diberi contoh pembelajaran modern, Peneliti setiap dua atau tiga minggu mengunjungi atau mengikuti guru tersebut dalam proses pembelajaran.

Temuan kedua, Kinerja guru meningkat dalam melaksanakan tindak lanjut hasil penilaian prestasi belajar peserta didik. Langkah-langkah yang dapat meningkatkan kinerja guru dalam supervisi edukatif kolaboratif adalah: (1) Peneliti dan guru bersama-sama membuat program tindak lanjut hasil penilaian, (2) Peneliti memberi contoh pelaksanaan tindak lanjut, yang akhirnya dilanjutkan oleh guru dalam pelaksanaan yang sebenarnya, (3) Peneliti mengajak diskusi pada guru yang telah membuat, melaksanakan, dan menganalis program tindak lanjut.

Supervisi merupakan salah satu tugas kepala sekolah yang bertujuan untuk membantu memperbaiki dan meningkatkan pengelolaan dari aspek yang disupervisi dan orang yang melakukan supervisi. Aspek yang disupervisi bisa berupa administrasi, dan edukatif, sedangkan orang yang melakukan supervisi adalahpengawas, kepala sekolah, instruktur mata pelajaran. Adapun orang yang disupervisi bisa kepala sekolah, guru mata pelajaran, guru pembimbing, tenaga edukatif yang lain, tenaga administrasi, dan siswa.

Hasil penelitian ini sesuai dengan hasil penelitian-penelitian sebelumnya yang dilakukan Miftah (2001) bahwa supervisi mampu meningkatkan kinerja guru. Di samping itu, hasil penelitian ini 
Supervisi Edukatif Kolaboratif untuk Meningkatkan Kinerja Guru Merencanakan Kegiatan Pembelajaran di SDN 01/X Rantau Indah Semester Ganjil Tahun Ajaran 2021/2022, Rosidah

sesuai dengan pendapat Sahertian (2000) bahwa salah satu upaya peningkatan kinerja guru adalah melalui supervisi pengajaran. Pelaksanaan supervisi pengajaran perlu dilakukan secara sistematis oleh Kepala sekolah dan Kepala sekolah bertujuan memberikan pembinaan kepada guru-guru agar dapat melaksanakan tugasnya secara efektif dan efisien. Dalam pelaksanaannya, Kepala Sekolah menggunakan lembar pengamatan yang berisi aspek-aspek yang perlu diperhatikan dalam peningkatan kinerja guru dan kinerja sekolah.

\section{KESIMPULAN}

Berdasarkan temuan hasil penelitian ada dua hal yang dikemukakan dalam penelitian tindakan sekolah ini mendapakan hasil yang lebih baik. Hasil penelitian menunjukkan bahwa melalaui supervisi edukatif kolaboratif dapat meningkatkan kinerja guru dalam merancang pembalajaran di SDN 01/X rantau Indah pada semester ganjil tahun ajaran 2021/2022.

Berdasarkan temuan-temuan penelitian tindakan ini, ada beberapa saran yang perlu disampaikan kepada pengambil kebijakan sekolah, di antaranya adalah; 1) Supervisi terhadap semua guru perlu dilakukan secara periodik dan ditetapkan pada awal tahun pelajaran (pada saat pembagian tugas), 2) Supervisi edukatif ternyata membawa peningkatan kinerja guru dan hasil belajar siswa jika dilaksanakan secara kolaboratif, 3) Supervisi edukatif kolaboratif akan bermakna jika Penelitinya adalah teman sejawat yang sudah mampu pada mata pelajaran yang bersangkutan, 4) Perlu memberi kesempatan pada guru-guru yang dianggap sudah mampu mensupervisi guru lain.

\section{REFERENSI}

A Dale, Timpe. (1993). Kinerja. Jakarta: PT. Gramedia. Bungin, Burhan. 2003. Analisis Data Penelitian Kualitatif. Jakarta: PT. Raja.

Ambar Teguh Sulistiyani dan Rosidah. (2003). Manajemen Sumber Daya Manusia, Cetakan. Pertama. Yogyakarta: Penerbit Graha Ilmu.

Aris suherman dan Ondi Saondi (2010) Etika Profesi Keguruan. Bandung: PT. Refika Aditama.

Basri, A. F. M., dan Rivai, V. (2005). Performance appraisal. Jakarta: PT. Raja. Grafindo Persada.

Dirjen Pendidikan Dasar dan Menengah Departeman Pendidikan Nasional (2004:2)

Hasibuan, Malayu S.P. (2005). Manajemen Sumber Daya Manusia. Edisi Revisi. Jakarta: Bumi Aksara.

Kusmianto. (1997). Panduan Penilaian Kinerja Guru oleh Pengawas.Jakarta

Kuswana, Wowo Sunaryo. (2008). Taksonomi Kognitif. Bandung: PT. Remaja Rosdakarya.

Manullang. (2005). Dasar_Dasar Manajemen. Gadjah Mada University Press. P.O.BOX

14 Bulaksumur, Yogyakarta

Mathis. L. Robert dan Jackson. H. John. (2001). Manajemen Sumber Daya Manusia. Jakarta: Buku kedua.

Miftah. (2001). Perilaku Organisasi, Konsep Dasar dan Aplikasinya. Raja Grafindo Persada, Jakarta 
Mulyasa. (2005). Menjadi Guru Profesional. Bandung: PT. Remaja Rosda Karya.

Mulyasa. (2007). Menjadi Kepala Sekolah Profesional. Bandung: PT remaja.

Purwanto, M. Ngalim. (2000). Psikologi Pendidikan. Bandung: Remaja.

Rivai, Veithzal (2004). Manajemen Sumber Daya Manusia untuk Perusahaan dari. Teori ke Praktik. Jakarta: PT Raja Grafindo Persada.

Rulyansah, A., \& Sholihati, M. (2018). Pengembangan Modul Berbasis Kecakapan Hidup pada Pelajaran Matematika Sekolah Dasar. MUST: Journal of Mathematics Education, Science and Technology, 3(2), 194-211

Rusman. (2010). Model-model Pembelajaran (Mengembangkan Profesionalisme. Guru Edisi Kedua). Jakarta: Raja Grafindo Persada.

Sahertian, Piet A. (2000). Konsep Dasar dan Tehnik Supervisi Pendidikan Dalam Rangka Mengembangkan Sumber Daya Manusia. Jakarta: Rineka Cipta

Slameto. (2012). Belajar dan Faktor-Faktor yang mempengaruhi. Jakarta: Rineka.

Surya, Mohamad. (2004). Psikologi Pembelajaran dan Pengajaran. Bandung: Pustaka. Bani Quraisy. Undang-undang No.20 tahun 2003 tentang Sistem Pendidikan Nasional.

UndangUndang Republik Indonesia Nomor 14 Tahun 2005 pasal 20 (a) Tentang Guru dan Dosen.

Undang-undang Sistem Pendidikan (2003:37). 